\title{
Means of Payment and the Use of Coins in the Viking Age Town of Birka in Sweden
}

\author{
Preliminary Results
}

\author{
Ingrid Gustin
}

\begin{abstract}
The article discusses aspects of the Viking Age trade and exchange in relation to means of payment. The analyses are based on the minted and unminted silver, as well as on the weights that were retrieved during the 1990-95 excavations of the Black Earth in Birka. It is stated that silver was primarily used for other purposes than small-scale transactions during the 8 th and 9 th centuries. However, the situation seems to have changed during the 10 th century. Silver, especially minted silver, was now highly fragmented and might have been used for exchange and trade in local products.
\end{abstract}

Ingrid Gustin, Department of Archaeology, Lund University, Sandgatan I, SE-223 50 Lund, Sweden.

\section{BARTER, EXCHANGE AND MEANS OF PAYMENT IN THE VIKING AGE}

When Viking Age trading-places are excavated, several types of objects are retrieved which might be used for interpreting how trade and exchange of goods was carried out in a society not yet dominated by modern market economy. The Scandinavian Viking Age world seems to have consisted of a society where different and contrasting economies and systems of exchange (gift-exchange - plunder, primitive economy - proto-market economy) existed side by side. In this society the exchange of goods could be carried out in different ways: through barter, credit or by means of payment. In contrast to modern society, means of payment were not standardised and completely based on coinage. Finds from Birka show that fragmented silver objects, Islamic coins, and pieces of bronze objects might have been used as means of payment, as well as beads of glass and rock-crystal. From historical sources we also know that cloth and furs were used by the
Vikings as means of payment (Sawyer 1985: 162; Jansson 1983:232).

There are many questions which can be raised in order to come closer to the character of Viking Age trade and exchange. In the following I will concentrate on how the material culture, through weights and coins, minted silver, as well as other silver objects (i.e. unminted silver), can be used for commenting on different types of economic transactions.

Two scholars with different opinions on whether barter, credit or the exchange of goods for means of payment was representative for the Viking Age, are Peter Sawyer and Heiko Steuer. According to Steuer, barter might have been used during the Viking Age, but barter was not the rule. Instead the exchange of goods was based on goods for weighed silver, in the form of fragmented silver objects or coins of first Islamic and then later English or German origin. Especially after 880 , when the import of dirhams started to increase, silver can be considered to be a standard of value as 
well as an article of exchange that was used everywhere. One of Steuer's main points is also that two different economic zones developed in Europe during the Viking Age. A western zone where exchange and means of payment were based on coins (Münzgeldwirtschaft), and an eastern zone with means of payment in the form of weighed silver (Gewichtgeldwirtschaft) (Steuer 1987a:122, 1987b:490).

Peter Sawyer, on the other hand, is of the opinion that trade even in a place like Hedeby, the most important trading-place in the Baltic area, must have depended mainly on barter or credit. According to Sawyer, the amount of coins found during the excavations in Hedeby and at other places in Scandinavia, is so small that coins can not have been the main medium of exchange during the 9th century. Sawyer also points out that large quantities of silver reached Scandinavia during the 10th and 11 th centuries, and that the inflow of silver seems to have stimulated the economy. This is shown by the changing character of the hoards, where the proportion of coins and small fragments of unminted silver increases. Sawyer maintains that silver, both in minted and unminted form, was now more commonly used in local trade, but that much of the local trade in Scandinavia was still done by barter (Sawyer 1990:285286).

The question of whether barter and credit, or exchange based on means of payment, predominated during the Viking Age is of course almost philosophic. A specific proportional relation between different ways of exchange can hardly be established, since it is impossible to say whether or not the artefacts found on archaeological sites have been used for barter and credit. The analysis must therefore be restricted to the existence and changing amount of objects, such as minted and unminted silver, which can be categorised as means of payment. Furthermore I consider it problematic to comment on the economic situation in general for such a vast and differentiated region as Scandinavia. Recent studies have shown that Scandinavia and the Baltic region can be divided into several subregions with different economic character and chronology (Hårdh 1996:166). I will therefore concentrate on the artefacts from just one place, Birka. The archaeological material that will be used is from the recent excavations in the Black Earth, that took place in Birka from 1990 to 1995.

\section{BIRKA: A TRADING-PLACE IN THE BALTIC REGION}

Birka is situated on the island of Björkö, an island with a central position in the lake Mälaren, Sweden. Foreign ships could reach the trading-place in Mälaren through a long strait from the Baltic. From Björkö the waterway could be followed either north to the old central region of Uppland, or west to the inner regions of the Mälar valley.

Hedeby and Birka, and perhaps also Wollin, are considered the main trading-places around the Baltic during the Viking Age. Hedeby was probably the leading tradingplace. The occupied area in Hedeby is 30 hectares, and it has been estimated that there are between 3000 and 7000 graves around the trading-place (Sawyer 1993:147; Ambrosiani \& Clarke 1993:138). The area of Birka's Black Earth - i.e. the stratified deposits from the occupation - is about seven hectares and the number of graves has been estimated to $\mathrm{c}$. 3000 (Ambrosiani 1992:11). Hedeby as well as Birka can be dated back to the 8th century.

Even today there are visible remains of the trading-place of Birka. The hillfort and its surrounding rampart is a landmark from afar. The surviving parts of the town rampart mark the extent of the Black Earth. Terraces of stone indicate several foundations for jetties (Ambrosiani \& Erikson 1991:16). The grave mounds are spread out in the landscape, forming cemeteries. During the summer, when the water of Mälaren sinks to low levels, wooden piles can be seen in the water immediately outside the former harbour. The piles were once part of a defensive system which blocked the entrance to the harbour from invaders. And finally there is one more monument which 
should be mentioned in connection with Birka. On Adelsö, the island next to Björkö, archaeological remains indicate that a royal manor was established on the island in the middle of the 8 th century. The manor was situated on a plateau overlooking the strait to Björkö and Birka.

Birka has been of interest to historians and scientific researchers since the 17 th century. At the end of the 19th century c. 1000 graves were excavated, and trenches were dug through the Black Earth. In 1990-95 new excavations were undertaken in the Black Earth. About $300-350 \mathrm{~m}^{2}$ of the central part of the occupation area was excavated. During the excavation the layers were dug stratigraphically using single context planning. Each deposit was machine- and water sieved, a process which recovered all finds of $2 \mathrm{~mm}$ and larger. More than 70000 find records were registered from the site, even though parts of the trench had already been submitted to excavation in the 1870 s.

The excavation showed that Birka existed as a trading-place as early as the 8th century. During the first 100 years the main part of the excavated area was used for activities connected with metalworking and bronze casting. In the middle of the 9 th century the central plot was left open for a time. The excavated houses on adjacent plots from this time do not show the same concentration of artefacts connected with handicrafts, as could be seen from the bronze casting.

\section{MINTED AND UNMINTED SILVER FROM THE 1990-95 EXCAVATION IN BIRKA}

A large number of the objects retrieved from the site bear witness to the different handicrafts that were practised on the excavated plot, as well as on adjacent plots. Bronze casting dominated the production for a long time. Semi-manufactured combs and rods of glass indicate a minor production of beads and combs at different times. Other types of objects bear witness to the trade and exchange that took place on the site. Minted and unminted silver, and different types of weights and fragments of balances indicate economic transactions. In the following I will use the amount of weights, minted silver and unminted silver, as well as the weight of the silver objects, to analyse how transactions were carried out in Birka.

From the excavated area of 1990-95, altogether 66 objects of unminted silver were retrieved. The objects were mainly fragmented and weighed from $0.05 \mathrm{~g}$ to $17.33 \mathrm{~g}$. Much of the material found at a low level in the trench was damaged by corrosion, and the objects from these earliest phases might have lost a great deal of weight during conservation. The silver objects found consisted of 30 objects and fragments of jewellery, 17 pieces of undefined scrap, 12 semi-manufactured pieces (rods, wire), and seven pieces of ingots. The total weight of these objects was $136.61 \mathrm{~g}$. All weights in this text refer to values after conservation.

The minted objects have been analysed by Gert Rispling of the Numismatic Research Group at the Department of Archaeology, Stockholm University. The material consists of 106 prehistoric coins or fragments of coins or coinlike objects. Of these, 89 are made of silver and 18 are made of coppper. Seven of the copper coins have been silver- or goldplated. Ninety coins were of Islamic origin, five were Byzantine, one was Nordic, one Roman and nine were blanks. Two hoards with coins were retrieved. The first hoard consisted of five Islamic coins, the second of 19 Islamic coins and several other objects relating to economic transactions. The stratigraphic position of the smaller hoard is uncertain. The larger hoard is from the first half of the 10th century and has a clear stratigraphic position.

Fourteen coins belonging to the two hoards are unfragmented. Of the remaining material only 11 coins are unfragmented. Most coins are highly fragmented and pieces consisting of $1 / 10$ of a coin or even $1 / 20$ are not uncommon. The total weight of the minted silver and silverplated copper amounts to $84.79 \mathrm{~g}$.

The proportional relation between whole 
and fragmented objects in hoards, as well as that between minted and unminted silver, has been used for discussions about the economic situation and intensity of trade in different regions in the Viking Age and early Middle Ages (see Lundström 1973:9 and the cited literature as well as Hårdh 1996). Most of the objects found at Birka are fragmented. Of course it will be of interest to analyse different degrees of fragmentation, but the most striking change in the Birka material seems to be the proportional relation between minted and unminted silver. Therefore I have chosen to start with this aspect.

\section{THE PROPORTION OF MINTED AND UNMINTED SILVER DURING \\ DIFFERENT PHASES OF THE SITE}

The stratigraphy of the site excavated in Birka 1990-95 has been divided into eight phases. Furthermore the objects found in the ploughsoil were retrieved, and these finds from the latest stratigraphic unit, S1, can be considered as constituting a final phase.

Since the post-excavation work is far from finished, the grouping as well as the dating of the phases must be regarded as preliminary. The first two sequences, B1-B2, seem to contain material which represents the 8th century. B3, B4, and B5 belong to the first half of the 9th century. B6 seems to be the only sequence from the second half of the 9th century. B7-B8 represent the first half of the 10 th century, and the material from the ploughsoil, S1, seems to represent the last 20 years of the existence of Birka, that is c. 95070.

The first two tables below present the amount of minted and unminted silver objects for each sequence. The earliest sequence is put at the bottom of the table. The hoard, consisting of 18 dirhams and one blank as well as other objects, is placed separately since this find might represent a different act from unintentionally lost pieces of minted and unminted silver in the occupation layers. For this reason the hoard will neither be included in tabs. 3 and 5 , nor in the diagrams.

\begin{tabular}{|l|c|c|}
\hline phase & $\begin{array}{l}\text { minted silver or } \\
\text { silverplated } \\
\text { coins, number }\end{array}$ & $\begin{array}{l}\text { unminted } \\
\text { silver, } \\
\text { number }\end{array}$ \\
\hline S1 & 23 & 10 \\
B8 & 3 & 3 \\
the hoard & 19 & - \\
B7 & 7 & 5 \\
B6 & - & 1 \\
B5 & - & 2 \\
B4 & 1 & 5 \\
B3 & - & 5 \\
B2 & 1 & 6 \\
B1 & - & 5 \\
\hline
\end{tabular}

Tab. l. Minted and unminted silver objects for each phase of the 1990-95 excavation in Birka. Preliminary results.

As can be seen from tabs. 1 and 2, the numbers do not represent all retrieved minted and unminted silver objects, and therefore do not correspond to the total amount of retrieved objects mentioned earlier in the text (see above). The reason for this is that it has not yet been possible to place all retrieved silver objects in a phase. This is either due to the fact that some objects had lost their original stratigraphic context before they were recovered (e.g. in the 19th-century trench), or to the fact that the post-excavation work on the stratigraphy is not altogether completed at the time of writing. However, by roughly estimating to which phases the remaining objects belong, it has been possible to establish that the tendencies of the material will remain the same. Since a final version of a stratigraphic analysis, based on the 1990-95 excavation still lies somewhere in the future, I decided it was worthwhile to present the minted and unminted silver objects from the excavation and to point out some main tendencies.

Tabs. 1 and 2 present the number and the weight of objects which have been placed into phases. The extent of the stratified deposits varied among the phases. Therefore it is hard to compare the amount of fragments and objects from one sequence with another. An 


\begin{tabular}{|l|c|c|}
\hline phase & $\begin{array}{l}\text { minted silver } \\
\text { and silver } \\
\text { plate, weight }\end{array}$ & $\begin{array}{l}\text { unminted } \\
\text { silver, } \\
\text { weight }\end{array}$ \\
\hline S1 & $13.33 \mathrm{~g}$ & $2.39 \mathrm{~g}$ \\
B8 & $1.75 \mathrm{~g}$ & $18.61 \mathrm{~g}$ \\
the hoard & $29.47 \mathrm{~g}$ & - \\
B7 & $5.08 \mathrm{~g}$ & $3.36 \mathrm{~g}$ \\
B6 & - & $0.31 \mathrm{~g}$ \\
B5 & - & $3.23 \mathrm{~g}$ \\
B4 & $0.08 \mathrm{~g}$ & $5.04 \mathrm{~g}$ \\
B3 & - & $5.91 \mathrm{~g}$ \\
B2 & $2.48 \mathrm{~g}$ & $11.64 \mathrm{~g}$ \\
B1 & - & $13.61 \mathrm{~g}$ \\
\hline
\end{tabular}

Tab. 2. The weight of minted and unminted silver objects for each phase of the 1990-95 excavation in Birka. Preliminary results.

additional problem with comparing the sequences is the corrosion that has affected the metal objects.

As mentioned before, especially objects from the earlier phases were severely damaged by corrosion. There are also other problems connected with corrosion that have to be considered. Minted silver in Birka, in the form of Islamic dirhams, is thinner than unminted silver objects in the form of ingots and rods. Thinner objects are probably more likely to be thoroughly corroded than denser objects. This might influence especially objects from the earlier phases, where the corrosion was generally high. Since the two pieces of minted silver from B1 and B4 are 1/1 and 1/20 part of an Islamic dirham, and since the original weight for a dirham is known ( $2.97 \mathrm{~g})$, the weight loss can be estimated to c. $17 \%$ for the whole coin and c. $50 \%$ for the fragment. In spite of the relatively high percentages, the figures for the minted silver will not change much, in comparison with the higher figures for the unminted silver material for the same phases in tab. 2. Furthermore the figures for the unminted silver objects ought to be considerably higher, since many of them are highly deteriorated. Unfortunately it is very complicated to estimate their weight loss.
Yet another problem in connection with corrosion is that the deterioration of metal objects is not only dependent on contact with water and oxygen. The deterioration of an object is also dependent on the structure and chemistry of the surrounding soil. For example, bronze objects found in the paths of Birka are more corroded than objects found in or close to houses. This is probably due to the wastelayers in the paths of the town (Mattsson \& Nord 1996:69). This could, of course, also influence the figures for the minted and unminted silver, which are presented in tab. 2 .

These critical observations must be kept in mind when discussing the weight of the silver objects. The question is whether these observations are able to alter the major trends shown in tab. 3.

\begin{tabular}{|l|l|l|}
\hline time span & $\begin{array}{l}\text { percentage } \\
\text { minted } \\
\text { silver/ } \\
\text { silverplated } \\
\text { coins }\end{array}$ & $\begin{array}{l}\text { percentage } \\
\text { unminted } \\
\text { silver }\end{array}$ \\
\hline $950-70$ & $85 \%$ & $15 \%$ \\
$900-49$ & $24 \%$ & $76 \%$ \\
$850-99$ & $0 \%$ & $100 \%$ \\
$790-849$ & $9 \%$ & $91 \%$ \\
\hline
\end{tabular}

Tab. 3. The percentage of minted and unminted silverduring four periods according to the 1990-95 excavation in Birka. Preliminary results. The hoard is not included in this tab.

Tab. 3 shows the percentage of minted and unminted silver for different time periods. The figures are based on the weights presented in tab. 2. To be able to later compare the material from Birka with other regions the time span will be divided into the periods $790-849,850$ $99,900-49$, and $950-70$. The periods and the Birka-phases might not correspond exactly to one another, but might still give some idea of a general development. B2-B5 correspond to the first period, $790-849$.

To come closer to an answer as to whether the percentages for each period might be con- 
sidered to be representative for the objects before they started to corrode, each period has to be analysed separately.

Since there are just two pieces of minted silver for the phases B1-B6, and since the approximate weight loss for these objects can be estimated, it is possible to maintain that the percentage of unminted silver remains very high for the first two periods, 790-849 and $850-99$. Furthermore it is likely that the percentage of unminted objects ought to be even higher, since some of the unminted objects have obvious weight loss after conservation.

It is harder to find an answer as to whether the percentages for the period 900-49 might change when the effects of corrosion are considered. But the proportion of unminted silver is as high as $76 \%$, so there is reason to believe that unminted silver would dominate even if, hypothetically, the weight of the minted silver proved to be a bit higher. Even if we add 17$50 \%$ to the weight of the minted silver, as for the period $790-850$, this will hardly change the general tendency.

The relation between minted and unminted silver for the period 950-70 might also be considered to be reliable. Objects from this period were retrieved from the ploughsoil and have been under the same conditions for a long time. It is therefore probable that the corrosion of minted and unminted silver objects is the same. Thus the analysis made above has shown that the tendencies seen in tab. 3 may be used for further analysis.

The figures shown in tabs. 1,2, and 3 are based on a small material, and a single object might sometimes change the result considerably. Therefore I shall restrict myself to comment on major changes. Tabs. 1,2, and 3 show that unminted and minted silver have circulated in Birka from the very beginning. The proportion of unminted silver is probably as high as $91-100 \%$ of all retrieved silver objects from the 9 th century. Different studies have showed that silver objects from the 10th and 11 th centuries were produced from Islamic coins (Arrhenius et al. 1973; Hårdh 1976:110_ 119). The dirham from phase $B 2$ indicates the possibility of a small import of Islamic coins as early as the 8 th century. If this was the case, these imported coins could have been used for the production of different objects such as rods, ingots, wire and jewellery. The demand for silver objects was probably great from very early on in Birka. It is also of interest to note that there was a need for silver as means of payment at this time, since we found fragmented silver objects as well as coins. It should, however, be mentioned that the circumstances of the finds show a high correspondence between silver objects and layers related to metalworking and bronze casting.

During the first half of the 10th century the unminted silver objects are of the same type as during previous sequences. Instead a change in the relation between minted and unminted silver appears, and the domination of unminted silver is not as strong as before.

The greatest change in the relation between minted and unminted silver occurs during the last part of Birka's existence. At this time 85\% of the silver is minted. The total weight of the minted silver is relatively high considering that only a small part of the ploughsoil was sieved, and that the ploughsoil only represents about 20 years. So what are the reasons behind the change in the proportion of minted and unminted silver?

\section{THE INFLOW OF DIRHAMS}

The silver hoards found in Sweden and the Baltic region give a general picture of the import of Islamic coins during different periods. The hoards are generally dated by the most recent coin, and thus a tpq for the time of hoarding is achieved. According to T. S. Noonan, there is a continual increase in the number of hoarded coins in mainland Sweden from the $780 \mathrm{~s}$ to the $860 \mathrm{~s}$. The number of hoarded coins during the 860 s to the 890 s is among the highest for the period from the late 8 th to the early 11 th century. During the first decades of the 10th century the numbers appear to lie on the same level as during the first half of the 9th century. A great increase 
occurs again during the 950s-70s (Noonan 1994:223).

\begin{tabular}{|l|l|l|}
\hline time span & $\begin{array}{l}\text { number of } \\
\text { hoarded } \\
\text { dirhams in } \\
\text { the Baltic } \\
\text { region }\end{array}$ & $\begin{array}{l}\text { number of } \\
\text { hoarded } \\
\text { dirhams in } \\
\text { mainland } \\
\text { Sweden }\end{array}$ \\
\hline $950-69$ & 34662 & 5265 \\
$900-49$ & 29545 & 3263 \\
$850-99$ & 13175 & 4307 \\
$770-849$ & 5146 & 470 \\
\hline
\end{tabular}

Tab. 4. The number of hoarded dirhams in the Baltic region and in mainland Sweden, according to Noonan.

Tab. 4 shows that the largest number of dirhams in mainland Sweden, as well as in the whole of the Baltic region, seems to have been present in the first decades of the second half of the 10 th century. The period $950-69$ can be regarded as equivalent to phase $\mathrm{S} 1$ in Birka. It is also during this period that dirhams and fragments of dirhams seem to have been deposited most frequently in Birka.

We have now been able to establish that there must have been a general and considerable increase in the number of dirhams in mainland Sweden, including Birka, in the middle of the 10th century. Therefore it seems plausible that the increased amount of lost coins in Birka in the 950s and 960s is due to the fact that more coins than ever circulated at the trading-place.

Still, the greater inflow of Islamic coins does not altogether explain the changing relationship between minted and unminted silver. During previous periods dirhams might have been remelted and used for indigenous metalwork, such as rods, ingots and wire as well as jewellery. The question now is whether the demand for these objects was satisfied in the 10 th century, and whether therefore the increase in the inflow of silver thus no longer needed to result in a consequent remelting of coins. This suggestion, however, seems less probable. Unminted silver is found in all sequences, including $\mathrm{S} 1$ where the amount of unminted silver still accounts for $15 \%$ of the total weight. That the weight of the objects is as little as $2.39 \mathrm{~g}$, might be due to the fact that $\mathrm{S} 1$ is based on a smaller area compared with other sequences.

Instead it remains probable that the need for silver as a means of payment increased, and that the inflow of silver made it possible to use silver to a greater extent than before.

To investigate the extent that silver was used as means of payment, we have to look into the question of whether the increase in the amount of minted silver during the last 20 years of Birka was due to a drop in the value of silver. It has already been established that dirhams in large numbers were present in the Baltic region in the middle of the 10 th century. An increase in the import of silver might have led to an abundance, which made the loss of a piece of a coin less important. If the abundance of silver had led to inflation, the fragments of silver correspondingly ought to have got heavier during the final phase (SI) in Birka.

To examine the last assumption it is therefore necessary to analyse the degree of fragmentation for different periods, to see whether the fragmentation of silver objects actually increases.

\section{FRAGMENTATION OF THE MINTED/ UNMINTED SILVER IN BIRKA}

Tab. 5 shows the number of minted and unminted silver objects in different classes according to their weight. The 19 coins of the hoard have not been included in tab. 5 .

The fact that many objects had lost weight due to corrosion might again lead to problems when comparing different periods with each other. As mentioned, objects from the early sequences might have lost a lot of their original weight. Another problem is related to the period 950-70 and phase $S 1$. This phase represents the ploughsoil, and larger artefacts of 
silver might have been found and removed during the centuries when the soil was cultivated. Therefore it is of great importance to use the table in a very wide sense. Nevertheless the table can be used for establishing that fragments less than $1 \mathrm{~g}$ increase, and that nearly all of the deposited fragments in $\mathrm{S} 1$ (period 950-70) were less than $1 \mathrm{~g}$. Therefore it seems less probable that silver lost its value when the inflow of dirhams increased in the Baltic region. However, the increasing degree of fragmentation must have made it easier to lose silver and, therefore fragmentation might have been a factor that contributed to the increase in deposited silver objects during the last phase of Birka.

To shed light on how the increasing amount of silver fragments was handled, it is necessary to compare the amount of deposited fragments with the amount of deposited weights.

\section{MEANS OF PAYMENT AND WEIGHTS}

Weights for weighing precious metals appear in Birka mainly in the form of lead weights (often cylindrical), cubo-octahedral bronze weights, and spherical bronze-covered iron weights with flattened poles. The weights from previous excavations in Birka have been presented by Ola Kyhlberg and Erik Sperber (Kyhlberg 1973, 1980; Sperber 1993). The excavation 1990-95 meant that about 300 weights could be added to the little more than 300 that were already known from the graves and from the excavated area of 1969-71. From the excavation in 1990-95 it was clear that cylindrical lead weights often appeared in connection to bronze-casting activities. One function of these weights must therefore be related to the work shop. The cubo-octahedral bronzeweights and the spherical weights with flattened poles have on the other hand been closely linked to the economy. These two types of weights appeared in the Baltic region around 870/890 A.D. Heiko Steuer has used their presence to define a zone where Gewichtsgeldwirtschaft prevailed, that is a zone where means of payment were weighed and not counted (Steuer 1987b:460, 480-489).

Weights as well as silver objects can be said to reflect economic transactions. Both were involved when weighed silver was about to pass from one person to another. As mentioned above, I will try to see whether the weights from the 1990-95 excavation together with the minted and unminted silver can shed light on the question of how silver was handled in Birka. To help answer the question, I have made diagrams which show the four last phases. Here I will concentrate on the sequences from the second half of the 9th century and later, since the material from previous sequences might be heavily influenced by weighing in connection with bronzecasting. Each diagram presents the number of weights, pieces of minted silver, and pieces of unminted silver that belong to the phase. The figures for the silver are based on tab. 1. The figures for the weights are presented for the first time in the diagrams, and they are based on the number of weights that so far have been possible to put into phases. Only a few weights remain.

In the diagrams, the sectors of each circle indicate the percentage of the three different groups in relation to one other. In B6, the amount of weights ( 7 in number) is $87.5 \%$ of the total sum of weights, minted and unminted silver together. During B7 the amount of weights decreases to about $66 \%$. In $\mathrm{B} 8$ the trend continues and the weights constitute about $65 \%$ of the material. In S1 the weights

\begin{tabular}{|l|c|c|c|c|c|}
\hline time span & $>\mathbf{4} \mathbf{g}$ & $\mathbf{4 - 3} \mathbf{g}$ & $\mathbf{3 - 2} \mathbf{g}$ & $\mathbf{2 - 1} \mathbf{g}$ & $<\mathbf{1} \mathbf{g}$ \\
\hline $950-70$ & & & 1 & 1 & 31 \\
$900-49$ & 1 & & & 3 & 14 \\
$850-99$ & & & 3 & 4 & 9 \\
$770-849$ & 3 & & 3 & & \\
\hline
\end{tabular}

Tab. 5 .

The fragmentation of minted/unminted silver according to the 1990-95 excavation in Birka. Preliminary results. The hoard is not included in this tab. 


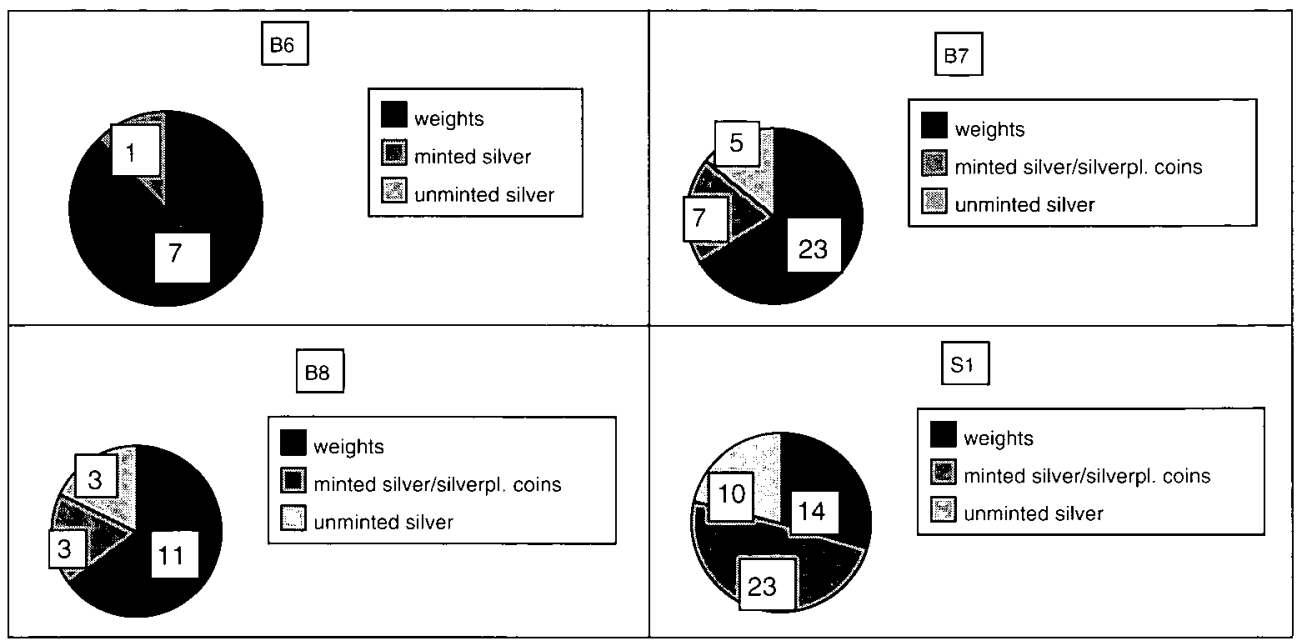

Diagrams 1-4. The amount of weights, minted and unminted objects for different phases in Birka. In the diagrams the numbers represent the actual amount of objects for each category. The percentage of each category is indicated by circle.

are not more than $30 \%$ of the total sum of weights, minted and unminted silver.

If we believe that weights were lost with the same frequency during the late 9 th and the 10 th century, then the result indicates that the number of weighing transactions did not increase at the same rate as did the amount of deposited silver objects. This can be due to different circumstances. Of course there is the possibility that weights became scarce during the second half of the 10th century, and that they therefore were not dropped to a great extent any longer. The amount of weights in each sequence does not indicate any decrease, however. Instead the number of weights seems to increase from the second half of the 9 th century to the second half of the 10th century. This indicates that weights were handled more frequently and probably that the number of transactions increased over time. Still, the proportionally larger increase in lost silver objects remains to be explained.

\section{CONCLUSION}

As has been shown, means of payment in the form of silver has been present from early on in Birka. The silver from the 8th and 9th centuries that we have been able to retrieve, was in the form of fragmented silver objects such as jewellery, ingots and rods. One question which still has to be answered is in what form silver was brought to Scandinavia during this time. If silver was brought here as coins, for example dirhams or sceattas, most of them seem to have been remelted. If silver coins first had to be remelted to indigenous silver objects and then in a second stage cut into pieces for use as a means of payment, this can be interpreted as if silver was primarily used for other purposes than small-scale transactions during the 8 th and 9 th centuries in Birka. These other purposes might be related to both the social and the economic sphere. Archaeological studies on economy have more and more focused on social and symbolical aspects of the different media which were used for economic transactions, such as gift-giving during the Viking Age (see Gaimster 1991; Samson 1991).

The weight of the retrieved silver objects from the 8th and 9th centuries in Birka was relatively high compared with later periods, which also indicates that silver was used for somewhat larger transactions during this period. Therefore it seems reasonable that other media were used for the local trade/exchange and 
minor transactions, or that there was another system for providing the inhabitants with subsistence goods.

During the first half of the 10th century the situation seems to change. The importation of dirhams to the Baltic has started to increase. The relation between minted and unminted silver in Birka has also started to change. If coins were remelted in earlier periods, there is now a change and the dirhams might not have been remelted to the same extent as before. The need for silver as a means of payment even for smaller transactions must have increased, and therefore dirhams were used primarily as such. The silver from the 10th century is highly fragmented and has probably been used for exchange and trade in local products. The number of weights compared with the number of silver objects has also started to change. The weights do not increase at the same rate as the silver.

During the last 20 years of Birka the inflow of coins seems to have been even higher than before. As many as 23 fragments of dirhams were retrieved from an area $50 \mathrm{~m}^{2}$. The fragments were probably deposited during a period of 20 years. During the same period only 14 weights were lost. The proportional relation between weights and silver thus changed. Weights seem to have been used proportionally less than before. This could indicate that whole and fragmented coins were now so common that they were accepted without weighing. This conclusion is also supported by the fact that the balances that were made and used during the second half of the 10th century, were less precise than before (Steuer 1987b:463). This leads to the conclusion that weighing primarily was used for larger transactions. The possibility that fragments of coins were used without weighing has also been discussed by Sucholdski and Hårdh (Hårdh 1996:25).

If fragments of coins were used without weighing, people who otherwise would not have had the possibility to own and use balances and weights, could be involved in transactions based on silver as a means of payment. Therefore there is a possibility that new or extended groups in Birka and the surrounding region now came in contact with and used silver coins as a medium in exchange situations. At this time it might also have been easier for a large group of people to use silver instead of barter. Barter must at times have been a complicated form of exchange involving several people, in order to get the object one really had a need for.

The analyses made on the archaeological material from Birka thus can be used for commenting on the economic situation in this trading-place and town during different periods. The initial discussion of whether barter or silver as a means of payment can be said to have dominated, can therefore be commented on again.

The results from the analyses indicate that Peter Sawyer's general view might be applicable to Birka: namely that the increased import of dirhams that started in the $880 \mathrm{~s}$ in the Baltic region stimulated the economy. The increased fragmentation of silver indicates that some sort of economic change started. But in Birka this change seems to have included a wider use of fragmented silver than indicated by Sawyer when he writes that barter and credit dominated in trading-places during the Viking Age. Heiko Steuer has pointed out that silver was the dominant exchange medium, and that barter was not the rule during the Viking Age. But in contrast to the general picture given by Steuer, the results from Birka thus far indicate that fragmented silver did not have an increased availability at this tradingplace until the middle of the 10th century. At this time a changed attitude to coins as a means of exchange in Birka can be concluded from the fact that fragments of coins might not have been weighed to the same extent as before.

Finally, it can be concluded that parts of a new process had started with the use of coins and fragments of coins in Birka that were not weighed. This process is dependent on a general acceptance of the value of certain silver coins. The next step of the process is indigenous minting. There are no traces of this in Birka. 
But about 30 years after the abandonment of Birka, around A.D. 1000, the first indigenous minting can be found in a new town, Sigtuna, which was established in an inlet of Mälaren, north of Birka.

English revised by Laura Wrang.

\section{ACKNOWLEDGEMENTS}

Special thanks to Monika Fjastad and Karin Lindahl, Conservation Department, Central Board of National Antiquities, and to Gert Rispling, Numismatic Research Group, Department of Archaeology, Stockholm University. Their work has been essential for this article and they have generously shared their knowledge with me. A special thanks also to Aidan Allen, who corrected the English of an earlier version of this text.

\section{REFERENCES}

Ambrosiani, B. 1992. What is Birka? In: Ambrosiani, B. \& Clarke, H. (Eds). Investigations in the Black Earth. Volume 1. Birka Studies. Birka Project, RA ̈̈/SHM. Stockholm.

Ambrosiani, B. \& Clarke, H. 1993. Vikingastäder: Wiken. Höganäs.

Ambrosiani, B. \& Erikson, B. 1991. Birka, vikingastaden. Vol. 1. Wiken. Höganäs.

Arrhenius, B., Linder-Welin, U.S. \& Tapper, L. 1973. Arabiskt silver och nordiska vikingatidssmycken. Tor XV. 1972-1973. Uppsala.

Gaimster, M. 1991. Money and Media in Viking Age Scandinavia. In:Samson, R.(Ed). SocialApproaches to Viking Studies. Cruithne Press. Glasgow.

Hårdh, B. 1976. Wikingerzeitliche Depotfunde aus Siidschweden. Probleme und Analysen. Liber/ Gleerup. Lund.

- 1996. Silver in the Viking Age. Acta Archaeologica Lundensia. Series in $8^{\circ}$, No. 25 . Almquist \& Wiksell. Stockholm.

Jansson, I. 1983. Gotland och omvärlden under vikingatid - en översikt. In: Jansson, I. (Ed). Gutar och vikingar: SHM. Stockholm.

Kyhlberg, O. 1973. Viktlod. In: Ambrosiani, B. et al. Birka, Svarta Jordens hamnområde, arkeologisk undersökning 1970-1971. Riksantikvarieämbetets rapport $\mathrm{Cl}$. Stockholm.

- 1980. Vikt och värde. Arkeologiska studier $i$ betalningsmedel, metrologi och värdemätning under yngre järnålder. I. Helgö. II. Birka. Stockholm Studies in Archaeology 1. Stockholm.

Lundström, L. 1973. Bitsilver och betalningsringar: Studier i svenska depaifynd frän vikingatiden påträffade mellan 1900 och 1970. Stockholm.

Mattsson, E. \& Nord, A. 1996. Statistical evaluation. In: Mattson, E. et al. Konserveringstekniska studier. Deterioration of archaeological material in soil. Results on bronze artefacts. Riksantikvarieämbetet och Statens historiska museer. Rapport. RIK 10. Stockholm.

Noonan, T. S. 1994. The Vikings in the East. Coins and commerce. In: Ambrosiani, B. \& Clarke, H. (Eds). The Twelfth Viking Congress. Volume 3. Birka Studies. Wiken. Höganäs.

Samson, R. 1991. Economic Anthropology and Vikings. In: Samson, R. (Ed). Social Approaches to Viking Studies. Cruithne Press. Glasgow.

Sawyer, P. 1985. Kungar och vikingar: Norden och Europa 700-1100. Norstedt. Stockholm.

- 1990. Coins and commerce. In: Jonsson, K. \& Malmer B. (Eds). Sigtuna papers. Commentationes de nummis saecolorum IX-XI. Kungliga Vitterhets Historie och Antikvitets Akademien. Stockholm.

Sawyer, B. \& Sawyer, P. 1993. Medieval Scandinavia from Conversion to Reformation circa 800-1500. University of Minnesota Press. Minneapolis.

Sperber, E. 1993. Finds of weights from the 1988 excavation. In: Holmquist Olausson, L. Aspects on Birka. Investigations and surveys 19761989. Theses and Papers in Archaeology B:3. Arkeologiska forskningslaboratoriet, Stockholms universitet. Stockholm.

Steuer, H. 1987a. Der Handel der Wikingerzeit zwischen Nord- und Westeuropa aufgrund archäologischen Zeugnisse. In: Düwel, K.J. et. al. (Eds). Untersuchungen zu Handel und Verkehr der vor-und frühgeschichtlichen Zeit in Mittel- und Nordeuropa. Teil IV. Der Handel der Karolinger- und Wikingerzeit. Vandenhoeck \& Ruprecht. Göttingen.

- 1987b. Gewichtsgeldwirtschaft im Frühgeschichtlichen Europa. In: Düwel, K.J. et. al. (Eds). Untersuchungen zu Handel und Verkehr der vor- und friihgeschichtlichen Zeit in Mittelund Nordeuropa. Teil IV. Der Handel der Karolinger- und Wikingerzeit. Vandenhoeck \& Ruprecht. Göttingen. 
